\title{
Lichenometric application to historical and subrecent dynamics and sediment transport of a Corsican stream (Figarella River-France)
}

\author{
F. Gob ${ }^{\mathrm{a}, *}$, F. Petit ${ }^{\mathrm{a}}$, J.-P. Bravard ${ }^{\mathrm{b}}$, A. Ozer ${ }^{\mathrm{a}}$, A. Gob ${ }^{\mathrm{c}}$ \\ ${ }^{a}$ Department of Physical Geography, University of Liege, 2 Allée du 6 Août, Bat. B11, 4000 Liège, Belgium \\ ${ }^{\mathrm{b}}$ Lumière University, Lyon 2 and Institut Universitaire de France, 5 Avenue Pierre-Mendès-France, 69676 Bron Cedex, France \\ ${ }^{\mathrm{c}}$ Department of Historical Sciences, University of Liege, $1 \mathrm{~b}$ Quai Roosevelt, Bat. A4, 4000 Liège, Belgium
}

Received 13 January 2003; accepted 22 April 2003

\begin{abstract}
Lichenometry has been applied to blocks, canyon walls and terrace deposits. A growth curve, specific to Corsica, was made based on information obtained from tombstones, old monuments from the Genoese occupation of Corsica and Roman megaliths. This allowed us to create a curve going as far back as 2000 years. The curve is similar to those developed in Mediterranean environments (Cévennes and Eastern Pyrenees), but is very different from those developed in Alpine and Arctic regions.

Lichens present on boulders of the bedload allow the time at which the boulders were laid down to be determined. The lichenometric study of the Figarella shows firstly that there is high stream competence. Blocks approximately $100 \mathrm{~cm}$ wide are moved during the 5-year flood. Recent important flood events were identified in 1973 and 1869. These correspond well with historical sources. Other older and much more important floods were also identified. This analysis has allowed us to extend the specific streampower curves proposed by Costa (Geol. Soc. Am. Bull. 94 (1983) 986) and Williams (Geogr. Ann. 65A (1983) 227) to blocks of more than $2 \mathrm{~m}$ wide.

Lichens present on the canyon walls and on terrace sides in the plain allowed the last main incision phase to be dated to the Little Ice Age. Aerial photograph analysis has shown that the present braided system in the lower course of the river is no longer active. (C) 2003 Elsevier Ltd. All rights reserved.
\end{abstract}

\section{Introduction}

The principle aim of lichenometry is date substrata using the diameter of lichens present, knowing that a correlation exists between lichen size and age and that the substrata must be exposed and stable in order for lichens to grow.

Rhizocarpon geographicum is the most common lichen species used (Innes, 1985). As there are many variations of this species the group name, $R$. geographicum (sensu lato), is commonly used rather than the species name. This very slow-growing lichen may live for several thousand years (Benedict, 1970) and is therefore of interest to geomorphologists studying Glacial and Late Glacial Holocene formations (André, 1985). The most widespread application of lichenometry is in polar regions and alpine areas, in studies mainly concerning moraine deposits (Andrews and Weber, 1969; Mat-

\footnotetext{
*Corresponding author. Tel.: +32-4-366-5257; fax: +32-4-3665722.

E-mail address: fgob@ulg.ac.be (F. Gob).
}

thews, 1973; Miller, 1973; Osborn and Taylor, 1975), rock glaciers (André, 1992), hillslope deposits (Benedict, 1967; André, 1985), and debris flow and avalanche activity (Innes, 1983; McCarroll, 1993). This technique has also allowed changing snow patch extent (Iwafune, 1997) and fault motions in Central Asia (Nikonov and Shebalina, 1979) to be evaluated.

Lichenometry has also been used in fluvial environments, firstly by Gregory (1976), who proposed defining river capacity by reconstructing and dating flood limits based on lichens present on bedrock and river banks. The presence of $R$. geographicum on terraces, alluvial fans and on bedload material of present-day valley floors has allowed sedimentary sequences to be dated (Harvey et al., 1984; Macklin et al., 1992; Maas et al., 1998). More recently, the application of this methodology to individual boulders has led to the reconstruction of a significant sequence of paleofloods (Maas et al., 2001).

We used this technique in a Corsican torrent where lichens are present on boulders of bedload measuring many meters, on rocky canyon walls and on pebbles that 


\section{Figarella Basin}

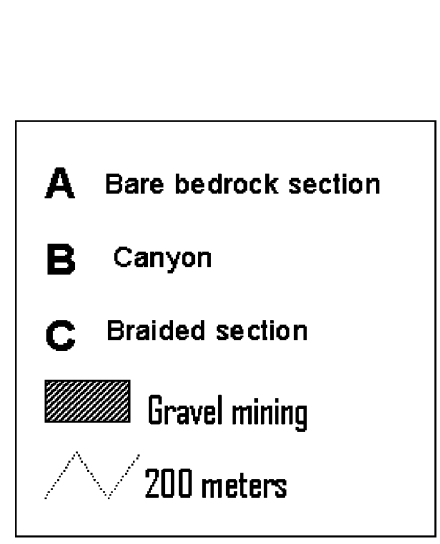

\section{(1)}
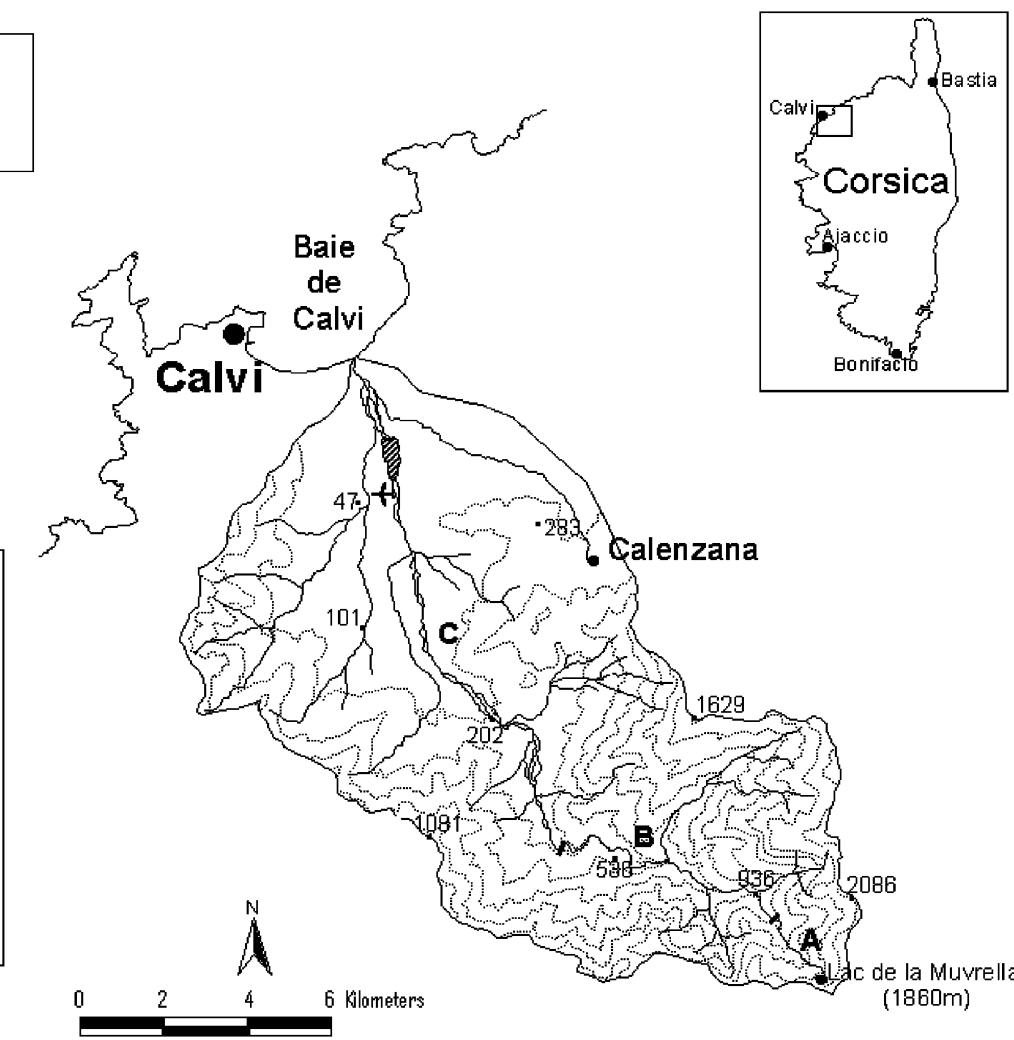

Fig. 1. Locational map of the Figarella catchment.

form the inherited stony layers in the lower reach of the river. The aim of our study was to evaluate boulder transport and to combine it with specific streampowers, to date river incision in the alluvial stony sheet and to evaluate lateral motion of the braided bed in the lower course of the Figarella River. For this last part, we compared the lichenometric study to a diachronic aerial photograph analysis of the floodplain.

\section{Study site}

The study involves the $133 \mathrm{~km}^{2}$ Figarella River Basin, in Northeast Corsica (Fig. 1). The source of the river is at an altitude of $1850 \mathrm{~m}$ and flows into Calvi Bay after only $24 \mathrm{~km}$, giving it a mean slope of $7 \%$. The basin is composed of only Porphyroïdic granite, but the lower reach is characterized by a dominance of fluvial Quaternary deposits. The $24 \mathrm{~km}$ of the profile may be divided into three morphologically distinct reaches (Fig. 2).

\subsection{Headwater stream}

The Figarella River flows directly on the bedrock in a narrow valley. The bed resembles a toboggan (slide), with alternating falls and long stretches of bare slabs of bedrock (Fig. 3). This reach $(2.5 \mathrm{~km}$ long with a mean

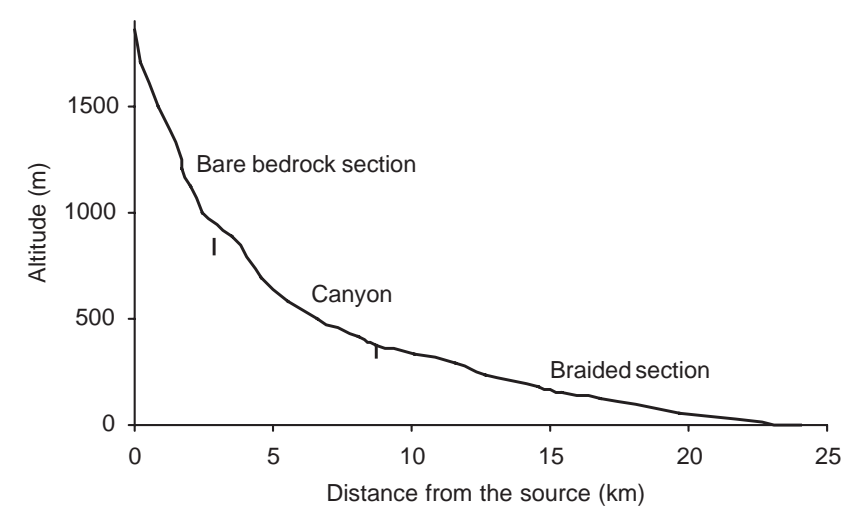

Fig. 2. Longitudinal profile.

slope of $0.325 \mathrm{~m} \mathrm{~m}^{-1}$ ) is almost completely free of bedload, except for a number of dispersed heaps of large angular boulders that have fallen from the steep valley sides. The appearance of the valley would lead one to think that boulders are evacuated as soon as they are produced - that is if, in fact, they are still produced by the valley sides.

\subsection{Canyons}

Widening and narrowing of the bed corresponds to the appearance of vegetation on the more gently sloping 


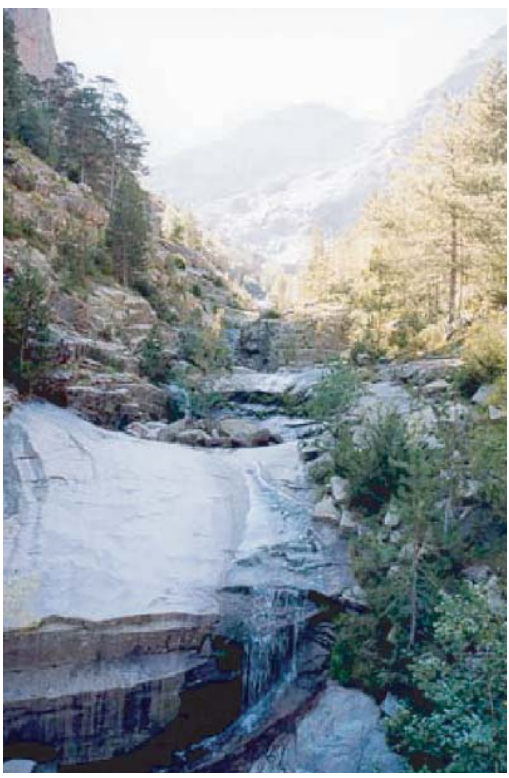

Fig. 3. Bare bedrock bed where blocks are directly evacuated downstream.

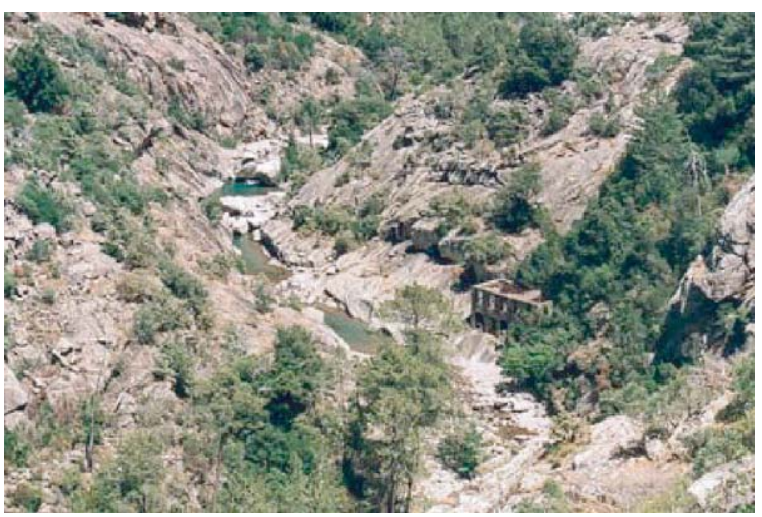

Fig. 4. Canyon, bare bedrock alternates with thin boulder layer.

valley sides. A thin layer of rough material covers the granite slabs that make up the riverbed. The bed is organized into reaches of large boulders, where steppool systems may develop (initiated by a narrowing of the bed), and reaches where the boulders are smaller and there are patches of exposed bedrock (evidence that the stony layer is not thick) (Fig. 4). In the lower part of the canyon the valley widens again and an incised meander appears. Here we find old fluvial deposits at a level above that of the present-day riverbed, that are up to $5 \mathrm{~m}$ thick and reach up to $20 \mathrm{~m}$ wide (Fig. 5).

\subsection{Braided section}

From the 9th kilometer onwards, the surrounding summits are lower and the valley clearly widens, reaching nearly $500 \mathrm{~m}$ in width. Braiding develops

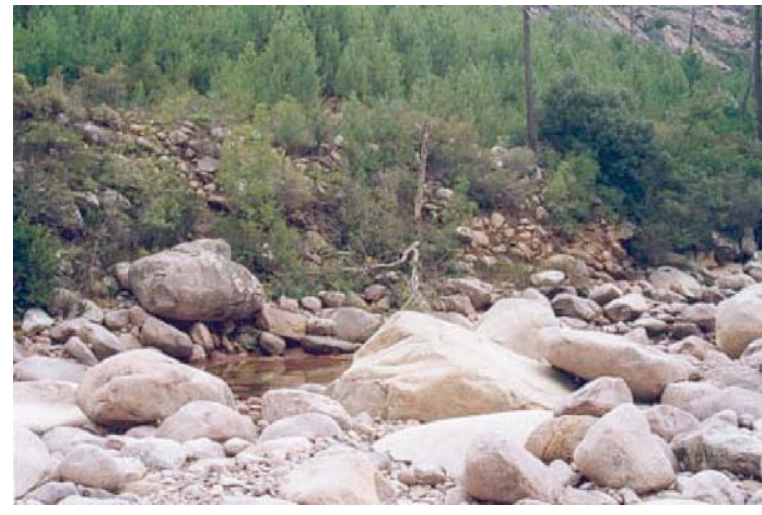

Fig. 5. Alluvial terrace $(5 \mathrm{~m}$ high) in the first meander of the canyon.

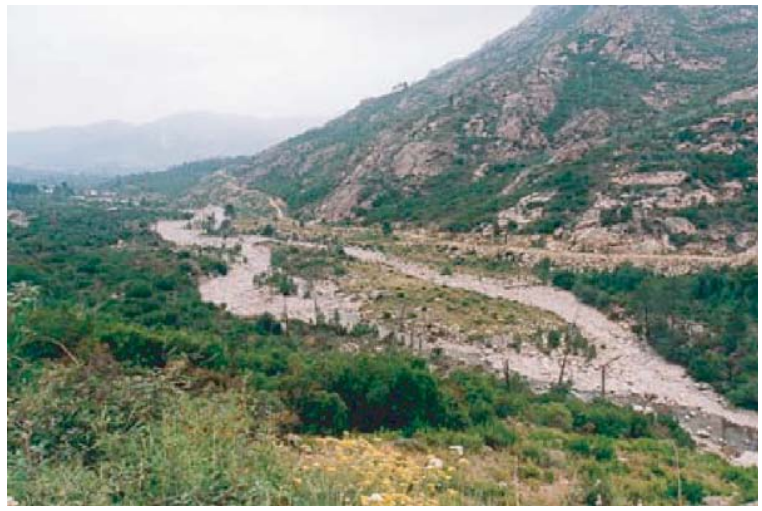

Fig. 6. Braided section (Point $\mathrm{C}$ in Fig. 1).

dividing the valley floor into several islets, which consist of boulders embedded in a sandy matrix. Channels have a width of between 20 and $35 \mathrm{~m}$ (Fig. 6). Islets and alluvial sheets range between 1 and $3 \mathrm{~m}$ high. With regard to flood marks identified, it appears that some of these are still regularly submerged. There are also former terraces $10 \mathrm{~m}$ above the bed, and other higher terraces $(20-25 \mathrm{~m})$ found further away.

\section{Material and methods}

\subsection{Dynamic parameters and granulometry}

The characteristics of the three sectors are summarized in 15 points (Table 1), using specific streampower in particular. This is a technique, which is increasingly used to characterize rivers (Petit, 1995; Piegay et al., 2000; Schmitt et al., 2001) and their activity (Ferguson, 1981; Brookes, 1988; Bravard, 1991). Several comments are called for in relation to the way that the data in this table were obtained. Specific streampower (expressed in $\mathrm{W} \mathrm{m}^{-2}$ ) is defined by

$\omega=(\rho g Q S) / w$, 
Table 1

Summarized table of morphologic, dynamic and granulometric parameters of the Figarella River

\begin{tabular}{|c|c|c|c|c|c|c|c|c|c|c|}
\hline & Site & $\begin{array}{l}\text { Distance } \\
\text { from the } \\
\text { source }(\mathrm{km})\end{array}$ & Altitude (m) & $D_{50}(\mathrm{~cm})$ & $\begin{array}{l}10 \text { largest } \\
\text { blocks }(\mathrm{m})\end{array}$ & $\begin{array}{l}\text { Catchment } \\
\text { area }\left(\mathrm{km}^{2}\right)\end{array}$ & $\begin{array}{l}\text { Slope } \\
\left(\mathrm{m} \mathrm{m}^{-1}\right)\end{array}$ & Width (m) & $Q_{1.5}\left(\mathrm{~m}^{3} \mathrm{~s}^{-1}\right)$ & $\begin{array}{l}\text { Specific } \\
\text { streampower } \\
\text { to } Q_{1.5} \\
\left(\mathrm{~W} \mathrm{~m}^{-2}\right)\end{array}$ \\
\hline \multirow[t]{2}{*}{$\begin{array}{l}\text { Headwater } \\
\text { stream }\end{array}$} & $\begin{array}{l}\text { 1. Punta di } \\
\text { Spasimata }\end{array}$ & 1.55 & 1290 & & 2.36 & 1.92 & 0.36 & 10 & 2.72 & 979.41 \\
\hline & $\begin{array}{l}\text { 2. Fontaine } \\
\text { de Spasimata }\end{array}$ & 2.05 & 1120 & & 3.63 & 4.28 & 0.29 & 12 & 5.17 & 1248.51 \\
\hline \multirow[t]{5}{*}{ Canyon } & $\begin{array}{l}\text { 3. Passerelle } \\
\text { suspendue } \\
\text { des Aiguilles } \\
\text { de Bonifatu }\end{array}$ & 3.65 & 890 & 48 & 4.54 & 8.85 & 0.22 & 17 & 9.24 & 1195.50 \\
\hline & 4. Confluence & 5.55 & 580 & 43 & 4.23 & 27.38 & 0.11 & 25.5 & 22.80 & 983.60 \\
\hline & $\begin{array}{l}\text { 5. Maison } \\
\text { forestière de } \\
\text { Bonifatu }\end{array}$ & 6.55 & 496 & 37 & 3.22 & 28.13 & 0.095 & 20 & 23.3 & 1106.75 \\
\hline & $\begin{array}{l}\text { 6. Bocca } \\
\text { Reza A }\end{array}$ & 8.05 & 412 & 34 & 2.39 & 33.78 & 0.06 & 25 & 26.97 & 647.38 \\
\hline & $\begin{array}{l}\text { 7. Bocca } \\
\text { Reza B }\end{array}$ & 8.75 & 380 & 27 & 3.09 & 35.3 & 0.06 & 21 & 27.94 & 798.31 \\
\hline \multirow[t]{8}{*}{$\begin{array}{l}\text { Braided } \\
\text { section }\end{array}$} & $\begin{array}{l}8.200 \mathrm{~m} \text { en } \\
\text { amont de la } \\
\text { confluence du } \\
\text { cours d'eau } \\
\text { de Frassigna }\end{array}$ & 10.15 & 330 & 27 & 1.72 & 37.11 & 0.055 & 92 & 29.08 & 173.86 \\
\hline & $\begin{array}{l}\text { 9. Champ de } \\
\text { tir de } \\
\text { Campanella }\end{array}$ & 11.55 & 285 & 13 & 1.335 & 48.43 & 0.045 & 25 & 35.98 & 647.72 \\
\hline & $\begin{array}{l}\text { 10. Gué à } \\
235 \mathrm{~m}\end{array}$ & 12.65 & 235 & 16 & 1.305 & 50.93 & 0.03 & 32 & 37.46 & 351.21 \\
\hline & 11. Ruzza & 14.55 & 180 & 18 & 0.948 & 61.66 & 0.035 & 25 & 43.65 & 611.15 \\
\hline & $\begin{array}{l}\text { 12. Pont de la } \\
\text { Figarella }\end{array}$ & 15.45 & 154 & 17 & 0.943 & 64.6 & 0.035 & 27 & 45.31 & 587.37 \\
\hline & 13. Aéroport & 19.7 & 59 & 13.5 & 0.727 & 82.2 & 0.025 & 30 & 54.94 & 457.86 \\
\hline & $\begin{array}{l}\text { 14. Ponte } \\
\text { Bambino }\end{array}$ & 23.45 & 5 & & 0.285 & 126.03 & 0.014 & 20 & 77.34 & 541.37 \\
\hline & $\begin{array}{l}15 . \\
\text { Embouchure }\end{array}$ & 24.05 & 0 & & & 129.375 & 0.008 & & 78.98 & \\
\hline
\end{tabular}




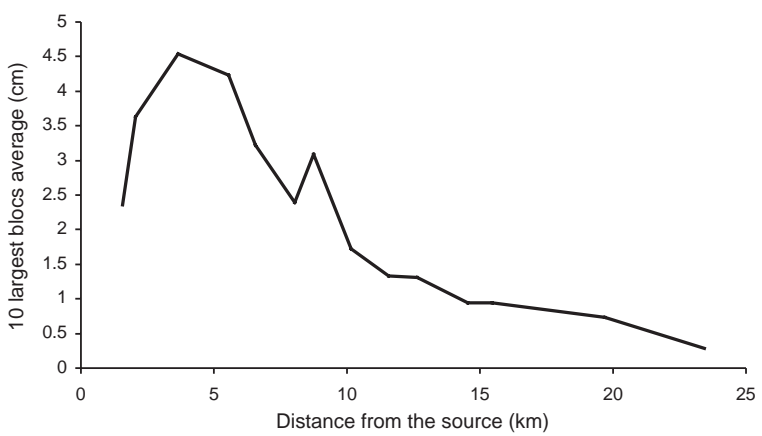

Fig. 7. Longitudinal distribution of particle size, determined by the average of the 10 largest blocks average.

where $\rho$ is the fluid voluminal mass $\left(\mathrm{kg} \mathrm{m}^{-3}\right)$ and $g$ the gravity $\left(\mathrm{m} \mathrm{s}^{-2}\right)$; thus, only $w$ the width (m), $S$ the slope $\left(\mathrm{m} \mathrm{m}^{-1}\right)$ and $Q$ the discharge $\left(\mathrm{m}^{3} \mathrm{~s}^{-1}\right)$ have to be measured. In order to compare rivers or reaches of rivers, the bankfull discharge $\left(Q_{\mathrm{b}}\right)$ is usually used, but in rivers where $Q_{\mathrm{b}}$ cannot be determined (braided rivers and canyons) the 1.5 years flood is used, because it is generally close to the bankfull discharge.

- Discharges were measured by the DIREN (Direction Régionale de l'Environment) between 1960 and 1976, at the Bonifatu station (the area of the basin here is $28 \mathrm{~km}^{2}$ ). The 1.5 years flood was calculated by adjusting the maximal annual flood sequence in the Gumbel distribution. We extrapolated the discharges upstream from the station using the relation

$q=Q(a / A)^{0.8}$,

where $q$ is the unknown discharge, $A$ the area of the basin at the measuring station $\left(\mathrm{km}^{2}\right)$ and $a$ the area of the basin upstream from the stretch of river studied (Bravard and Petit, 1997).

- Altitudes were determined from maps and verified using a precision altimeter. Knowing the distance from the source (read on 1:25,000 map), longitudinal slopes were calculated. In parts where more detailed measurements were necessary a clysimeter was used.

- Widths were measured on site. In the upper part, the width between the rocky walls bordering the bed was considered. In the braided section we considered the sum of the widths of each different channel because, as we shall see, even if islets are frequently submerged they may not be considered as active, the rough bedload is not transported and there is even some fine deposition.

- The mean diameter of gravelly materials $\left(D_{50}\right)$ was calculated using the linear granulometry technique developed by Wolman (1954). We also measured the $b$-axis of the 10 largest boulders, which comes close to the $D_{95}$ obtained from Wolman's technique (Fig. 7).

\subsection{Lichenometry}

It is known that $R$. geographicum grows at different rates according to micro-climatic conditions (moisture and temperature), substratum stability and growth season duration (snow-free) (Benedict, 1970; Innes, 1985), as well as local lighting (Hale, 1973). For this reason, it is important to construct growth curves for each region where lichenometry is to be used. Growth curves are usually determined using indirect dating - by measuring the maximum diameter of thalli growing on surfaces for which the age exposition is known. Measurements are mainly taken from historically dated monuments such as gravestones, archeological remains, or from other ${ }^{14} \mathrm{C}$-dated deposits (Benedict, 1967). Most existing curves (Miller, 1973; Grove, 1988; André, 1997) concern high-latitude environments, such as Spitsberg, Alaska and Baffin Island, or mountainous regions situated in relatively high altitudes, such as the Japanese Alps (Sekine in Iwafune, 1997), the British Uplands (Harvey et al., 1984), the Scandinavian Alps (McCarroll, 1993), the Colorado Front Range (Benedict, 1967) and the Bolivian Andes (Maas et al., 2001). This is understandable, given the technique's specific field of application. However, lichenometric curves for mountainous Mediterranean environments do not exist, although curves for the Cevennes and Eastern Pyrenees (Jacob et al., 2002) are now in progress.

During the development of the curve and during the fieldwork, lichen age was determined by calculating the average of the largest intermediary diameter for each of the five largest thalli present on the substratum. In theory, the largest lichen identified on a given block (i.e. the oldest) is also the closest in age to the date of deposition of that block. Therefore, only the largest thallus should be considered while developing the growth curve or establishing the substratum age. However, when thalli grow side by side, they often meet and coalesce. In this case, the limits of individual thalli are not easily distinguished. In order to reduce errors associated with considering these coalescences as a single thallus, the average of the five largest thalli is taken into account. Other studies have also used this method (Innes, 1985). However, on relatively small surfaces, such as tombstones, there are not always five large lichens. In this case the average is established using the maximum number of large thalli present.

The $R$. geographicum growth curve specific to Corsica was first elaborated using the results of lichen prospecting in the cemeteries of Calvi and its surroundings. However, after remarking the low regional variability, the prospecting area was extended to the entire island where we found several very old points (Fig. 8). Remains from the Genovese occupation of Corsica (XIII-XVIII century) as well as very old megaliths (Prehistoric) have enabled us to draw a curve that goes 


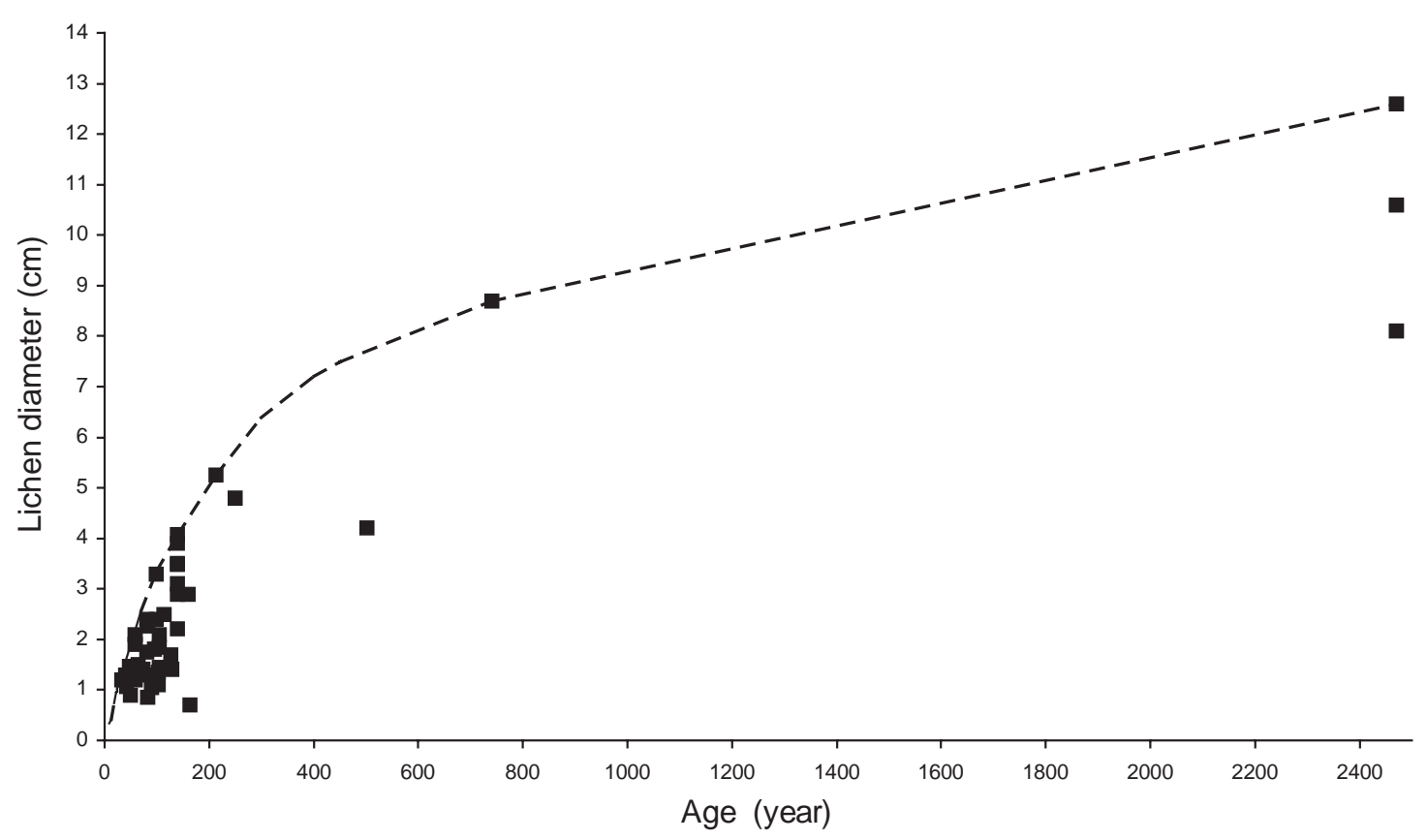

Fig. 8. R. geographicum growth curve for Corsica.

back over 2000 years. However, considering that the number of points available decreases with time, only the 300 last years can be dated with precision (within the margin of a few years). After this, the precision of the growth curve decreases. Nevertheless, the ages of oldest points remain reliable, as they were determined with historical assistance. The Cucuruzzu castle dates to the ninth century $\mathrm{BC}$; however, we must consider the date of abandonment, estimated between 600 and 259 BC. Three points were found at different places in the fortified complex. We attributed an age of 2470 years to these lichens (Grosjean, 1964, 1970; Jehasse and Grosjean, 1976; Bonifay, 1983). The Casteddu Di San Lorenzu is a medieval construction destroyed in 1259. One particular lichen found here was measured on a cut block proceeding from the destruction of the dungeon (this block is caught between two huge granite blocks, and has clearly not been disturbed since the dungeon was destroyed).

In Corsica, $R$. geographicum has a growth rate of $0.25 \mathrm{~mm}$ year $^{-1}$ during the first 200 years, and then $0.015 \mathrm{~mm}$ year $^{-1}$. This difference in growth rate is common to all curves found in other lichenometric studies. More details relating specifically to the Corsican curve and comparisons with other regional curves can be found in Jacob et al. (2002).

In the Figarella catchment, lichenometry was used in three different ways:

1. Dating terraces in the lower sector: In general, lichens present on terrace pebbles show the moment at which the gravel sheet was abandoned in the terrace, and thus the moment when the river began to incise. Indeed, when gravel forms the valley floor it is regularly transported, therefore preventing any lichen colonization.

2. Lichens on canyon wall: Lichens increase in size moving from the base to the top of the wall. The different sizes do not necessarily correspond to high water levels or flood limits, since we observed that $R$. geographicum may undergo frequent submersions. On the other hand, as we shall see, they may not resist sifting of the rough load transported by saltation. Increasing lichen size as one moves up the wall is considered to show either a bed incision phenomenon or a decrease in saltation height, and thus of river energy during floods.

3. Boulder transportation in relation to paleofloods: The presence of lichens on large blocks of the river bedload shows that these blocks are no longer transported. Indeed, transporting of boulders kills the lichens present. With this in mind, it is possible to gain an idea of the last time that the blocks were transported by using the age of the oldest lichens present. We related this to known important floods: on 26 September 1973, peak discharge was $153 \mathrm{~m}^{3} \mathrm{~s}^{-1}$ at the Bonifatu station (SOGREA). Although the discharge sequence is quite short, we tried to determine the recurrence of that flood, and conversely, the value of some characteristic discharges (Table 2). Note that the 1973 discharge gives a Coutagne-Myer coefficient close to 30. Such high values are not surprising in Corsica and in Mediterranean mountains in general because of the amount 
Table 2

Characteristic flood events recorded at the station "Maison Forestiere de Bonifatu",

\begin{tabular}{lcc}
\hline Flood & $\begin{array}{l}\text { Recurrence } \\
(\text { years })\end{array}$ & $\begin{array}{l}\text { Discharge } \\
\left(\mathrm{m}^{3} \mathrm{~s}^{-1}\right)\end{array}$ \\
\hline Bankful discharge $\left(Q_{\mathrm{b}}\right)$ & 1.5 & $23.3^{\mathrm{a}}$ \\
$\mathrm{Q}_{3}$ & 3 & $50^{\mathrm{a}}$ \\
Decennial flood & 10 & $99^{\mathrm{a}}$ \\
September 1973 & 50 & $153^{\mathrm{b}}$ \\
Centennial flood & 100 & $175^{\mathrm{a}}$ \\
\hline
\end{tabular}

${ }^{\text {a }}$ Recurrence determined by Gumbel's distribution.

${ }^{\mathrm{b}}$ Discharge recorded by the DIREN.

of precipitation and the basin slopes (Conchon and Gauthier, 1985). Besides, in historical documents there are traces of the Figarella flood of October 1869 , and the description of damages leads one to believe that it was more violent than the 1973 flood (BCEOM, 1997).

Specific streampowers reached during such floods were estimated, and particular attention was paid to the relation linking specific streampower and mobilized diameter, in order to extend the Williams and Costa relation to larger sizes. In order to date boulder transport, we worked on $150-200 \mathrm{~m}$ long straight reaches, where the river flows in only one channel. We systematically recorded all boulders with lichens in the bed. We then measured their diameter and $b$-axis. These measurements were recorded at five different sites.

\subsection{Aerial photograph analysis}

In the braided sector, we carried out a diachronic analysis based on five series of aerial photographs taken between 1951 and 1990 by IGN France. Considering the rather small scale of these pictures (between $1 / 27,000$ and $1 / 34,000$ ), we mainly worked on the area without vegetation that corresponds to the braided active band. After having digitalized, mosaïqued, and georeferenced the aerial series, we chose two zones. In order to enhance image readability, we applied a filter (edge enhance $5 \times 5$ available on Imagine software). Then we digitalized all of the area without vegetation on each series of pictures, and therefore the active channels.

The superposition of the channel of each picture shows that the riverbed has barely changed position, indicating that lateral erosion is almost non-existent. Moreover, the calculation of the area of the active band for each year (Fig. 9) clearly reveals that the vegetation of the bank colonized it in the early 1970s.

This phenomenon may be explained in several ways. It could simply confirm the dynamic modifications that the river has undergone since the end of the Little Ice

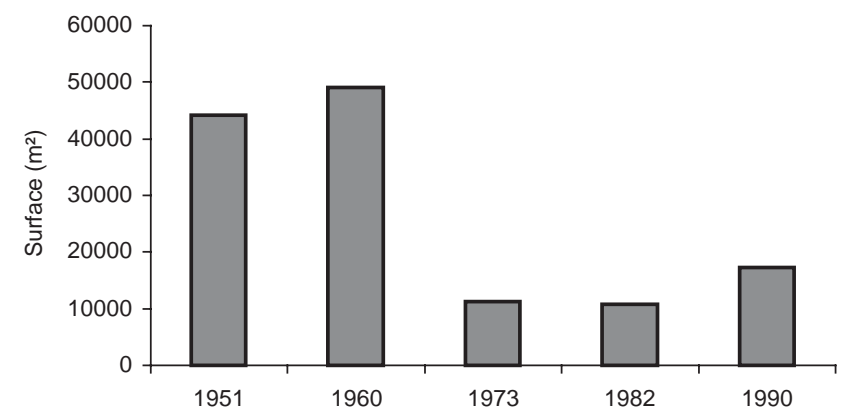

Fig. 9. Active band surface of a $2-\mathrm{km}-$ long reach in the braided section.

Age (see below) which have led the river to stop braiding. Gravel mining may also be responsible. Changes in the riverbed shown by the photographs of 1960 and 1973 may result from the influence of a gravel mining installation, only a few kilometers downstream, which extracted sediment directly from the riverbed. This may have caused bed incision upstream (by regressive erosion). Finally, significant land-use changes have taken place since the last century. The proportion of cultivated land in the watershed was $48 \%$ in the middle of the 19th century and is now only $16 \%$ (Gaillot and Piegay, 1999). Moreover, the late 1960s may correspond to a significant influx of "pied-noirs" from Algeria which may have resulted in changes to agricultural practices (abandonment of pastures on the floodplain, use of slash-and-burn techniques, firewood clearance, etc. in favor of vineyard culture) and therefore damage to the development of vegetation near the bed.

\section{Results}

\subsection{Boulder mobilization related to floods and determination of critical specific streampower}

In the canyon sector we measured lichens on blocks in order to estimate when they were last mobilized. The aim was two-fold: firstly, to identify the main floods of the past and then to determine the streampower at which blocks of a determined size were transported, thus refining existing relations of critical specific streampower (i.e. the streampower necessary to transport a size-determined element). Indeed few relations exist for rough gravel load, and these only cover materials to a maximum of $1 \mathrm{~m}$ (Costa, 1983; Williams, 1983; Petit et al., 2000).

The relations of lichen diameter to boulder size for the five different sites were plotted on graphs (see example in Fig. 10). First of all, we note the absence of lichens on blocks where the $b$-axis is smaller than $95 \mathrm{~cm}$. These boulders are regularly reshaped, allowing no time for the 


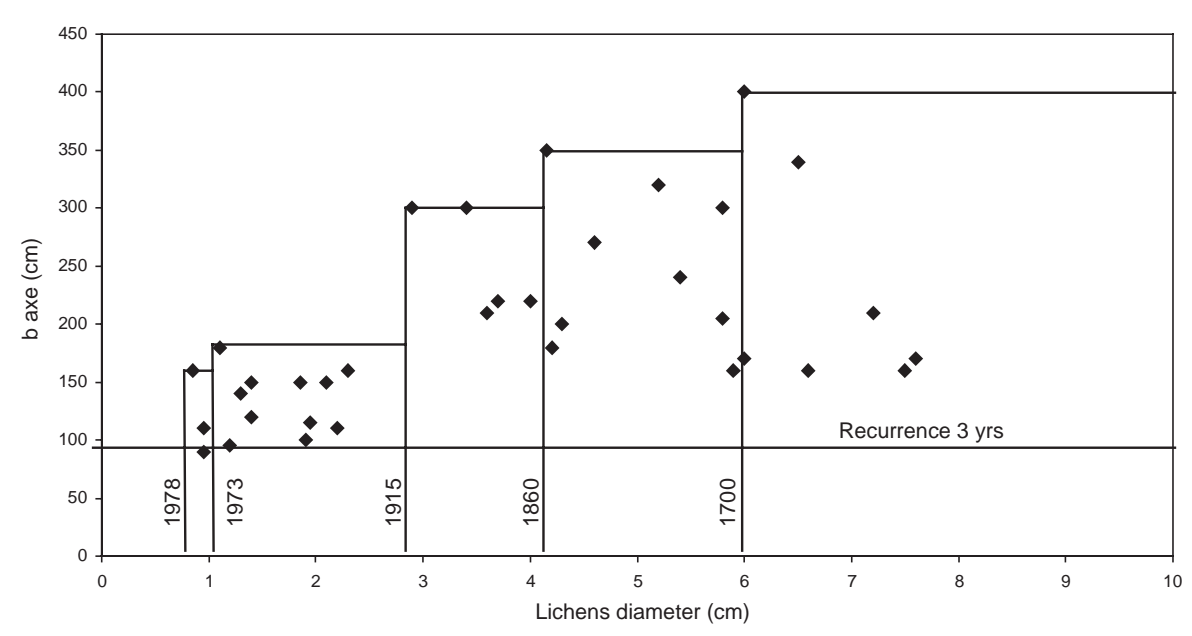

Fig. 10. Block size-lichen diameter relation at the "Maison Forestière de Bonifatu".

lichens to settle. The recurrence of a flood capable of transporting them is thus less than the time required for lichens to colonize the newly freed substratum. This time lapse can be estimated at 3-5 years, for two reasons: (i) the growth curve made for Corsica crosses the $X$-axis at around 3 years; (ii) during the making of the Rhizocarpon growth curve in Cévennes (Jacob et al., 2002) we noted that several tombstones which had been in place for less than 5 years did not show evidence of lichen growth, in spite of the fact that they were favorable for the implantation of lichens (unpolished granite gravestones, presence of lichens in surrounding areas allowing colonization by spores). This led us to hypothesize that a minimum of 3-5 years is required for thalli to start to develop. Therefore, boulders whose $b$-axis is smaller than $95 \mathrm{~cm}$ are transported by 3-5-year floods. Torrent competency seems quite high, as it can move blocks of around $1 \mathrm{~m}$ during rather common floods with a recurrence of less than 5 years.

Another prominent element (shown in Fig. 10) is the arrangement of points in tiers, which indicates the maximal dimension of transported blocks for a given lichen size. Some levels can be linked to the major floods of the Figarella that we have identified (1973 and 1869). The 1973 flood did not move blocks larger than $180 \mathrm{~cm}$. Besides, taking lichen measurements into account, we could expect there to have been a strong flood around 1915 (stronger than in 1973, but less than in 1869), but we found no evidence of this in written sources. Lichenometric dating, using the example of Fig. 6, shows another very important flood in the early XVIII century, since one finds blocks larger than $3 \mathrm{~m}$ wide with lichens of $6-7 \mathrm{~cm}$, which have not moved since. But as we shall see, this may also be interpreted in another fashion. In the other sites, the two more recent floods are well identified, but the more important floods do not seem to be present on each site. This may be explained by the imprecision of lichenometry for 100-year-old elements or by the position of certain thalli that did not allow them survive.

Moreover, we may highlight the elements that floods did not mobilize. From Fig. 6, we can see that the 1973 flood did not move a $2 \mathrm{~m}$ bloc. Such data are of particular interest because it serves as a countercheck to verify the relation between specific streampower and particle diameter.

In this regard two remarks are called for:

- For each level, we note that flood competency increases. This makes perfect sense considering that, as one goes back in time, only floods more important than those that are already recorded on the graph can be seen. Indeed, blocks transported by smaller floods were reshaped afterwards, destroying lichens that may have been present on the boulders. Taking into account the increasingly exceptional character of floods over time, we should find a longer time interval between the different tiers.

- There are very old lichens on relatively small blocks, which logically should have been reshaped during more recent floods. However, some bedload elements organize themselves in such a way that clusters form and the presence of a big boulder creates, both downstream and directly upstream, a zone where the dynamic conditions (shear stress and specific streampower) have to be much higher to destabilize particles (Reid and Hassan, 1992).

For each of the five measurement sites, we determined the maximal size of transported blocks for the 1973 flood and the $Q_{3}$ flood. We also calculated the specific streampower reached during these two floods, which actually corresponds to the critical specific streampower (Table 3). The relation that best fits the Figarella data $(r=0.95)$ is (Fig. 11):

$\omega_{0}=0.0253 d_{i}^{1.62} \quad($ range : $900-2000 \mathrm{~mm})$, 
where $\omega_{0}$ is the specific streampower of bedload mobilization and $d_{i}$ the mobilized particle size (expressed in $\mathrm{mm}$ ). This relation fits as a continuation of the relations proposed by Costa (1983) and Williams (1983), which appear respectively as follows:

$\omega_{0}=0.009 d_{i}^{1.69} \quad($ range : $50-1000 \mathrm{~mm})$,

$\omega_{0}=0.079 d_{i}^{1.3} \quad($ range : $10-1500 \mathrm{~mm})$.

Note that the equations proposed by Williams and Costa are not based on a straight regression, but on a curve that passes underneath the points. In the relation proposed for the Figarella, this gap is small, considering the weak point dispersal.

In the riverbed, blocks of around 3-4 $\mathrm{m}$ bear lichens $5-6 \mathrm{~cm}$ wide, showing that they have not moved since the early XVIII century. If we use the relation developed earlier, in order to move such blocks, a specific streampower as high as $17,000 \mathrm{~W} \mathrm{~m}^{-2}$ is required.
Considering the slope and width of the canyon, such a streampower corresponds to a discharge of about $400 \mathrm{~m}^{3} \mathrm{~s}^{-1}$, which, considering the catchment size, would give a Myer-Coutagne coefficient $(C$, defined by $Q=C A^{0.5}$ ) equal to 70 . In Mediterranean environments, such values are common. Indeed in the Ardèche River and its tributaries, this coefficient exceeds 100 (Pardé and de Beauregard, 1959). However, these blocks may not have been moved, but just released by movements of finer neighboring material. This does not exclude a slight downward movement during adjustment following this erosion. In a sense these blocks may represent a residual level resulting from the evacuation of an inherited rocky alluvial sheet.

\subsection{Lichens on canyon wall}

We measured the largest thalli present on a rocky canyon wall, which was subvertical and free of other

Table 3

Maximum and minimum size of blocks transported by the 3-year flood and the 1973 flood

\begin{tabular}{|c|c|c|c|c|}
\hline Sites & Floods & $\begin{array}{l}\text { Maximum sizes of } \\
\text { transported blocs }(\mathrm{mm})\end{array}$ & $\begin{array}{l}\text { Minimum sizes of non- } \\
\text { transported blocs }(\mathrm{mm})\end{array}$ & $\begin{array}{l}\text { Critical specific } \\
\text { streampower }\left(\mathrm{W} \mathrm{m}^{-2}\right)\end{array}$ \\
\hline Confluence & $\begin{array}{l}1973 \\
\mathrm{Q}_{3}\end{array}$ & $\begin{array}{r}1750 \\
900\end{array}$ & 1600 & $\begin{array}{l}4941 \\
1614\end{array}$ \\
\hline M.F. Bonifatu & $\begin{array}{l}1973 \\
\mathrm{Q}_{3}\end{array}$ & $\begin{array}{r}1800 \\
900\end{array}$ & 2000 & $\begin{array}{l}5508 \\
1800\end{array}$ \\
\hline Boca Reza B & $\begin{array}{l}1973 \\
Q_{3}\end{array}$ & $\begin{array}{r}2000 \\
850\end{array}$ & 2500 & $\begin{array}{l}3915 \\
1284\end{array}$ \\
\hline Petit Pont & $\begin{array}{l}1973 \\
\mathrm{Q}_{3}\end{array}$ & $\begin{array}{r}1400 \\
700\end{array}$ & 1450 & $\begin{array}{r}3056 \\
992\end{array}$ \\
\hline Aval Frassigna & $\begin{array}{l}1973 \\
\mathrm{Q}_{3}\end{array}$ & $\begin{array}{r}1000 \\
600\end{array}$ & 1100 & $\begin{array}{r}2022 \\
656\end{array}$ \\
\hline
\end{tabular}

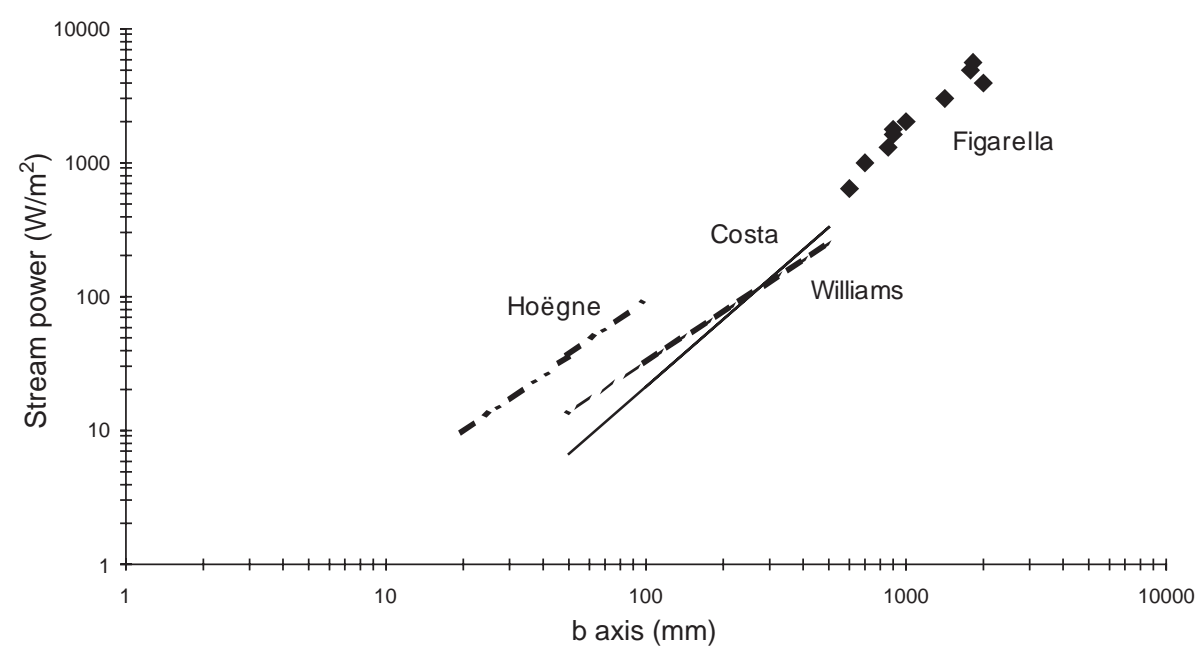

Fig. 11. $b$-axis-specific streampower relation in gravel bed rivers. Relations developed in the Figarella River, in the Hoëgne River by Petit et al. (2000), Costa (1983) and Williams (1983). 
Table 4

Largest lichen sizes measured on a rocky wall in the canyon

\begin{tabular}{lll}
\hline $\begin{array}{l}\text { Height on the wall } \\
(\mathrm{cm})\end{array}$ & $\begin{array}{l}\text { Largest lichen size } \\
(\mathrm{cm})\end{array}$ & $\begin{array}{l}\text { Age deducted from } \\
\text { the lichenometric } \\
\text { curves (years) }\end{array}$ \\
\hline $0-50$ & no lichen & 0 à 3 \\
$50-100$ & 2.4 & 67 \\
$10-150$ & 2.25 & 62 \\
$150-200$ & 2.08 & 55 \\
$200-250$ & 3.9 & 80 \\
$250-300$ & 7.9 & 575 \\
\hline
\end{tabular}

vegetation for $3 \mathrm{~m}$ from the base (Table 4). Above $3 \mathrm{~m}$, lichen size decreases. This may be explained by the presence of vegetation that inhibits thallus growth.

First of all, let us note that the absence of lichens until $50 \mathrm{~cm}$ does not correspond to the high water limit. Indeed, we observed flood marks at much higher levels. As will be confirmed in the braided section (see below), lichens may resist frequent submersions if they are in more or less protected areas. Other detailed analyses have shown an absence of lichens on the upstream face of blocks, while they are found on the downstream face. This shows that sifting by carriage or by saltation is a factor responsible for the destruction of lichens. This may also explain the lichen-free zone below the first $50 \mathrm{~cm}$.

The increasing size of $R$. geographicum on rock walls can be explained in two different ways: either by a decrease in the height reached by the particles during their transportation, or by bed incision. This incision did not occur in the bedrock, but rather to the detriment of a pebble sheet that would have been developed beforehand, probably during a cooler period. A similar situation is described in the Ardèche, during the Pleistocene.

The following evidence led us to think that the lichen arrangement in tiers is the result of an incision into the inherited pebble sheet. First of all, it is hard to believe that the bed load or even saltation could have reached a height of $3 \mathrm{~m}$, as this would have required incredibly important dynamic conditions that are rarely met, even during the exceptional floods in large bedrock rivers (Baker and Kochel, 1988). Moreover, in the canyon, where the river is larger, there are some tracks of a former pebble sheet (Fig. 5), which clearly show an incision into that inherited sheet. Taking into account the age of the lichens (about 550 years), the incision would have begun in the middle of the XV century.

\subsection{Braided section and terraces}

\subsubsection{Three main terrace levels}

Three main terrace levels are revealed in the braided section. One level at $+20-25 \mathrm{~m}$ high, another a dozen meters below $(+9-11 \mathrm{~m})$ and a third at $+3 \mathrm{~m}$, not counting the valley floor. Their disposition and relative altitudes correspond rather well to the inferior terraces described by Conchon $(1972,1978)$ in western Corsican valleys and by Ozer (1978) in Northern Sardinia.

We measured lichens that were on about 20 terrace fragments. Each value presented in Table 5 corresponds to a different terrace, which may be grouped into the three main levels. The highest level $(20-25 \mathrm{~m})$, colonized by high, dense scrub, does not bear any lichens; thus no dating is possible.

A dozen meters below, terraces bear lichens reaching a size of $11 \mathrm{~cm}$, corresponding to an age of about 1800 years. This leads us to think that the river began to incise and transform the pebble sheets in the terrace about 2000 years ago. Unfortunately, we do not know the date of the pebble sheet deposition and it is not possible to date the start of the incision with high precision.

The $+3 \mathrm{~m}$ level is the most represented in the valley floor. Terrace sides, colonized only by a small cover of thin scrub, are generally brown-red in color. The size of the largest lichens $(7 \mathrm{~cm}$, the 9.2 size has been excluded,

Table 5

Largest lichens sizes measured on the terraces in the lower reach of the Figarella River

\begin{tabular}{|c|c|c|c|c|c|c|c|c|}
\hline & \multicolumn{8}{|c|}{ Terraces levels (m) } \\
\hline & 1 & 2 & 3 & 4 & 6 & 9 & 11 & $20-25$ \\
\hline Lichens diameter $(\mathrm{cm})^{\mathrm{a}}$ & $\begin{array}{l}5.8 \\
5.9 \\
2.9\end{array}$ & $\begin{array}{l}4.8 \\
2.58 \\
2.8 \\
3.94 \\
3.56 \\
4.38 \\
2.64\end{array}$ & $\begin{array}{l}7 \\
6.9 \\
3.9 \\
9.2 \\
5.9 \\
4.15 \\
7 \\
3.9 \\
5.16 \\
7\end{array}$ & 7.5 & 7.35 & 11.25 & & \\
\hline
\end{tabular}

${ }^{\mathrm{a}}$ Lichens diameter is calculated from the longest axis average of the five largest lichens presents on the deposit. 
as it is not sufficiently represented) present on pebbles at the top and side of the terrace indicates that this terrace level would have been laid down about 400 years ago $( \pm 1600 \mathrm{AD})$.

Intermediary levels, between the three main ones (25, 10 and $3 \mathrm{~m}$ ), are represented to a much lesser extent and are not found on the whole plain. Therefore, they have not been considered as a characteristic level.

The current bed is a multiple channel bed, but at present braiding is not active. Indeed, some islets bear lichens nearly 250 years old (between 4 and $5 \mathrm{~cm}$ ). This shows that the islets have been fixed since then, and that lateral erosion is very low. Besides, $R$. geographicum, and therefore the islets, may be regularly submerged. Indeed we found flood marks on many of them. The diachronic study carried out using aerial photographs seems to confirm this hypothesis, at least for the most recent period.

In the braided section, three incision phases were highlighted, one of which can be dated with precision using lichenometry (Fig. 12). In that schema, final incision phases can be related to the coldest period of historical times, the Little Ice Age (1500-1850; Grove, 1988; Berger, 1992). Today, the braided system, which is likely to have been active during erosive phases, is fixed, probably due to very recent modifications (sediment extractions, changes in agricultural practices).

The last incision phase of the lower reach would correspond more or less to the incision phase revealed in the canyon by lichen distribution on the rocky walls (mid-XV century) and large residual blocks. The slight delay of about one century between the start of the incision in the canyon and in the plain could result from imprecision of lichenometric dating, or more probably because watersheds react more quickly than sections of the river further downstream, notably because of the sediment supply from upstream to downstream.

\subsubsection{Discussion}

The lichenometric dating of the lowest terraces of the Figarella River has allowed us to show that they were laid down during a cold period known as the Little Ice Age. This situation is contrary to what is usually seen in the rest of Europe. For instance, in the Alps it is wellknown that riverbeds rose and widened vigorously due to an increased supply of coarse material from the destabilized valley sides (Bravard, 1987, 1989; Peiry, 1989; Salvador, 1991; Peiry et al., 1994).

In his study of valleys of the Mediterranean basin, Vita-Finzi (1969) has shown that after the Mediaeval Climatic Optimum, marked by the filling of a large number of valleys, the Little Ice Age was synonymous with a return to erosion due to an increase in precipitation. Dufaure (1976), studying Holocene terraces in Olympia, also shows incision of terraces during the Little Ice Age (which was characterized by rainfall fluctuations) and explains it by a complex combination of climatic factors and human factors. Bruneton (1999) also notes an incision found throughout the valleys of the Alpilles (Provencia) during the same period, that she attributes to the organization of the valley sides in restanques, a terracing technique largely used at that time to limit erosion of cultivated parcels of land. Macklin et al. (1994, 1995) show in semi-arid fluvial systems of Mediterranean mountains that as the climate becomes more humid the vegetation cover increases, the sediment supply to valleys decreases and this then provokes an incision of major rivers. Besides, valley side degradations and aggradation of the valley floor are characteristics of low precipitation periods and of a decrease of vegetation cover.

Some exceptions to this schema have however been shown. For instance, in the Southern Alps where phases of hydromorphologic crisis affected the Durance River (late XIV century, 1540-1870) alternated with quieter
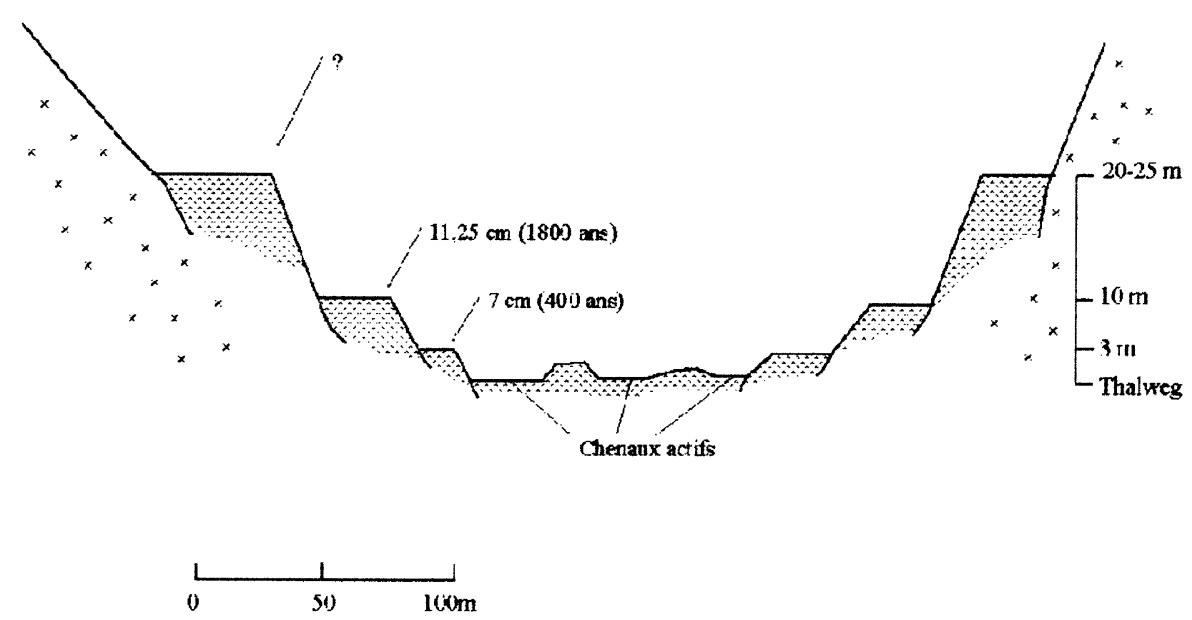

Fig. 12. Schema of the braided sector of the Figarella River. There are three different levels of terraces, the two lowest bear lichens and may therefore be dated (1800 and 400 years). 
phases (XX century, 1410-1540) without any large bed metamorphoses. Braided channels seem to have persisted throughout these climatic fluctuations, however with a bed widening during the Little Ice Age (Miramont et al., 1998). In Crete different units of deposits in a small basin seem to have formed during the coldest part of the Holocene, resulting from an important increase in the amount and size of sediments in response to both greater valley side erosion and more increased precipitation. One of these units would have been formed during the second half of the Little Ice Age, a period during which, in Crete, temperatures were significantly lower than those recorded at present and annual precipitation was greater (notably as snow) (Maas et al., 1998). These authors recognize, however, that the history of agricultural practices has been insufficiently documented in many Mediterranean basins, and that this does not allow the influence of populations on river evolution to be evaluated. In many basins, human activity on the valley slopes may indeed have prevented an increase of vegetation due to the change in climatic conditions and may have favored slope erosion. Another factor that should also be taken into account is the basins sensibility to erosion, in other words, the substratum resistance, which is directly related to the lithology.

Although little evidence testifies to human pressure that might have influenced the evolution of the Figarella Basin, its possible incidence cannot be disregarded. Indeed, human action is both very old and very strong in Mediterranean environments (Reille et al., 1996). From pollen analyses, these authors note a radical change in Corsican vegetation, notably by fire eradication and the complete dismantling of a Quercus level in recent historic times (XIV century).

\section{Conclusion}

From this study it is evident that lichenometry is of great interest in the study of rivers with large blocks. It is a particularly effective instrument with regard to determining the critical conditions for mobilizing blocks, and allows a relationship between the size of mobilized elements and the specific stream power of rivers transporting blocks of more than $1 \mathrm{~m}$ in diameter to be put forward. Such a relationship had not been proposed until now and extends the equations proposed by Costa (1983) and Williams (1983) for rivers with blocks of less than $1 \mathrm{~m}$ in diameter.

Another important aspect of lichenometry is that it allows the time at which terraces were formed, and therefore, erosive phases to be identified. While the majority of dating techniques generally used for this type of study provide a date for the laying-down of deposits, they do not allow identification of erosive phases. The Figarella underwent three major incision phases. From the growth curve established for Corsica, the beginning of the most recent phase was dated to approximately $400 \mathrm{BP}$.

This corresponds to the first part of the Little Ice Age. During this period Corsica would have experienced an increase in precipitation and a decline in temperatures. However, this would not have been as significant as for the Alps, favouring vegetation growth. The valley sides would not, therefore, have been very productive in terms of sediment, while at the same time liquid discharge would have increased sharply following increased rains. The sedimentary balance was therefore poor and the river could incise about $3 \mathrm{~m}$ deep. Although there are few indications that the Figarella basin may have undergone human influence, this cannot be ruled out.

\section{Acknowledgements}

The authors would like to thank the Professor J. Lambinon and Professor E. Sérusiaux for their advice on the biological aspects of this paper, F. Damblon from the Royal Institute of Natural Sciences of Belgium and Natasha Shields for translating the text. For this study, F. Gob has been granted by the F.R.I.A.

\section{References}

André, M.F., 1985. Lichénométrie et vitesses d'évolution des versants arctiques pendant l'Holocène (région de la baie du Roi, Spitsberg). Revue de Géomorphologie Dynamique 34, 49-72.

André, M.F., 1992. Les glaciers rocheux du Spitsberg central et nordoccidental. Revue de Géomorphologie Dynamique 41, 47-63.

André, M.-F., 1997. Holocene Rockwall retreat in Svalbard: a triplerate evolution. Earth Surface Processes and Landforms 22, 423-440.

Andrews, J.T., Weber, P.J., 1969. Lichenometry to evaluate changes in glacial mass budget as illustrated from north-central Baffin island, N.W.T. Artic and Alpine Research 1, 181-194.

Baker, V.R., Kochel, R.C., 1988. Flood sedimentation in bedrock fluvial systems. In: Baker, V.R., Kochel, R.G., Patton, P.C. (Eds.), Flood Geomorphology. Wiley, New York, pp. 123-137.

Bceom, 1997. Etude du risque d'inondation relative à la vallée de la Figarella et aux bassins versants littoraux péri-urbains de Calvi, étude réalise pour la DDE de Haute Corse, Bastia.

Benedict, J.B., 1967. Recent glacial history of an alpine area in the Colorado Front Range, U.S.A. Journal of Glaciology 6 (48), 817-832.

Benedict, J.B., 1970. Downslope soil movement in a Colorado Alpine Region: rates, processes and climatic significance. Artic and Alpine Research 2, 165-226.

Berger, A., 1992. Le climat de la terre. De Boeck Université, Bruxelles, $479 \mathrm{pp}$.

Bonifay, E., 1983. Informations archéologiques - circonscription de la Corse, Gallia-Préhistoire, pp. 511-525.

Bravard, J.-P., 1987. Le Rhône, du Léman à Lyon. La Manufacture, Lyon, 451pp. 
Bravard, J.-P., 1989. La métamorphose des Alpes françaises à la fin du Moyen Age et à l'époque moderne. Bulletin de la Société Géographique de Liège 25, 145.

Bravard, J.-P., 1991. La dynamique fluviale à l'épreuve des changements environmentaux: quels enseignements applicables à l'aménagement des rivières? La Houille Blanche 7, 515-521.

Bravard, J.-P., Petit, F., 1997. Les Cours d'eau: Dynamique du Système Fluvial. A. Colin, Paris, 222pp.

Brookes, A., 1988. Channelized Rivers: Perspectives for Environmental Management. Wiley, New York, 326pp.

Bruneton, H., 1999. Géomorphologie et évolution du milieu naturel depuis la fin du Würm. Carte Archéologique de la Gaule: Les Alpilles et la Montagnette 13/2, 47-58.

Conchon, O., 1972. Caractères généraux et chronologie relative des alluvions fluviatiles rubefiées de quelques vallées de Corse Orientale. Bulletin de l'Association Française pour l'Etude du Quaternaire 3, 171-184.

Conchon, O., 1978. Quaternary studies in Corsica (France). Quaternary Research 9, 41-53.

Conchon, O., Gauthier, A., 1985. Phénomènes naturels exceptionnels en Corse: intérêt pour l'étude géologique de la période quaternaire. Bulletin de la Société des Sciences Historiques et Naturelles de la Corse 648, 141-165.

Costa, J.E., 1983. Paleohydraulic reconstruction of flash-flood peaks from boulder deposits in the Colorado Front Range. Geological Society of American Bulletin 94, 986-1004.

Dufaure, J.J., 1976. La terrasse d'Olympie et ses équivalents méditerranées. Bulletin de l'Association des Géographes Français 433, 85-94.

Ferguson, R.I., 1981. Channel forms and channel changes. In: Lewin, J. (Ed.), British Rivers. G. Allen \& Unwin, London, pp. $90-125$.

Gaillot, S., Piegay, H., 1999. Impact of gravel-mining on stream channel and coastal sediment supply: example of the Calvi Bay in Corsica (France). Journal of Coastal Research 15 (3), 774-788.

Gregory, K.J., 1976. Lichens and the determination of river channel capacity. Earth Surface Processes 1, 273-285.

Grosjean, R., 1964. Le complexe torréen fortifié de Cucuruzzu (Lévie, Corse), première campagne de fouilles, 1963. Bulletin de la Société Préhistorique Française 61, 185-194.

Grosjean, R., 1970. Lueurs sur les plaques en bronze ajourées à bossettes du Post-torréen de Cucurruzzu (Lévie, Corse). Bulletin de la Société Préhistorique Française 67, 220-222.

Grove, J.M., 1988. The Little Ice Age. Methuen, Londres, 498pp.

Hale, M.E., 1973. Growth. In: Ahmadjam, V., Hale, M.E. (Eds.), The Lichens. Academic Press, New York, pp. 473-492 (Chapter 14).

Harvey, A.M., Alexander, R.W., James, P.A., 1984. Lichens, soil development and the age of Holocene valley floor landforms: Howgill Fells, Cumbria. Geografiska Annaler 66A (4), 353-366.

Innes, J.L., 1983. Lichenometric dating of debris flow activity in the Scottish Higlands. Earth Surface Processes and Landforms 8, 579-588.

Innes, J.L., 1985. Lichenometry. Progress in Physical Geography 9, $187-254$.

Iwafune, M., 1997. Application of lichenometry to the changing snow patch extent during the last several decades at Karasawa Cirque in Mt Hotakadake, the Northern Japanese Alps. The Science Reports of the Tohoku University, Series 7 (Geography) 47 (1-2), $17-33$.

Jacob, N., Gob, F., Petit, F., Bravard, J.-P., 2002. Croissance du lichen Rhizocarpon geographicum sur le pourtour nord occidental de la Méditerranée observations en vue d'une application à l'étude des lits fluviaux rocheux et caillouteux. Géomorphologie: relief, processus, environnement 4, pp. 283-296.
Jehasse, J., Grosjean, R., 1976, Livret-guide de l'excursion C4: Sites préhistoriques et protohistoriques de l'île de Corse. UISPP, Nice, $135 \mathrm{pp}$.

Maas, G.S., Macklin, M.G., Kirkby, M.J., 1998. Late Pleistocene and Holocene River development in Mediterranean Steepland environments, Southwest Crete, Greece. In: Benito, G., Baker, V.R., Gregory, K.J. (Eds.), Palaeohydrology and Environmental Change. Wiley, New York, pp. 153-165.

Maas, G.S., Macklin, M.G., Warburton, J., Woodward, J.C., Meldrum, E., 2001. A 300 years history of flooding in an Andean mountain river system: the Rio Alizos, southern Bolivia. In: Maddy, D., Macklin, M.G., Woodward, J.C. (Eds.), River Basin Sediment Systems: Archives of Environmental Change. Balkema, Rotterdam.

Macklin, M., Rumsb, B., Heap, T., 1992. Flood alluviation and entrenchment: Holocene valley-floor development and transformation in the British Uplands. Geological Society of America Bulletin 104, 631-643.

Macklin, M.G., Passmore, D.G., Stevenson, A.C., Davis, B.A., Benavente, J.A., 1994. Responses of rivers and lakes to Holocene environmental change in the Alcaniz Region, Teruel, northweast Spain. In: Millingtoné, A.C., Pye, K. (Eds.), Environmental Change in Drylands: Biogeographical and Geomorphological Perspectives. Wiley, Chichester, UK, pp. 113-130.

Macklin, M.G., Lewin, J., Woodward, J.C., 1995. Quaternary fluvial systems in the Mediterranean basin. In: Lewin, J., Macklin, M.G., Woodward, J.C. (Eds.), Mediterranean Quaternary River Environments. Balkema, Rotterdam, pp. 1-25.

Matthews, J.A., 1973. Lichen growth on an active medial moraine, Jotunheimen, Norway. Journal of Glaciology 12 (65), 305-313.

McCarroll, D., 1993. Modelling Late-Holocene snow avalanche activity: incorporating a new approach to lichenometry. Earth Surface Processes and Landforms 18, 527-539.

Miller, H.G., 1973. Late Quaternary glacial and climatic history of northern Cumberland Peninsula, Baffin Island, N.W.T., Canada. Quaternary Research 3, 561-583.

Miramont, C., Jorda, M., Pichard, G., 1998. Evolution historique de la morphogenèse et de la dynamique fluviale d'une rivière méditerranéenne: l'exemple de la moyenne Durance (France du Sud-Est). Géographie Physique et Quaternaire 52 (3), 381-392.

Nikonov, A.A., Shebalina, T.Y., 1979. Lichenometry and earthquake age determination in central Asia. Nature 280, 675-677.

Osborn, G., Taylor, J., 1975. Lichenometry on calcerous substrates in the Canadian Rockies. Quaternary Research 5, 11-120.

Ozer, A., 1978. Les terrasses du Coghinas (Sardaigne septentrionale). Proposition de chronologie. Studi Sassaresi, Serie III-Annali della Facolta di Agraria dell'Universita di Sassari 25, 78.

Pardé, M., de Beauregard, J., 1959. Quelques remarques sur les crues cévenoles de septembre et octobre 1958. Mémoires et Travaux de la S.H.F. 1, 38-49.

Peiry, J.L., 1989. L'utilisation du cadastre sarde de 1730 pour l'étude des rivières savoyardes: l'exemple de la vallée de l'Arve (HauteSavoie). Revue de Géographie de Lyon 64 (4), 197-203.

Peiry, J.L., Salvador, P.G., Nougier, F., 1994. L'incision des rivières dans les Alpes du nord: état de la question. Revue de Géographie de Lyon 69, 47-56.

Petit, F., 1995. Régime hydrologique et dynamique fluviale des rivières ardennaises. Demoulin, A. (Ed.), L'Ardenne, essai de géographie physique, hommage au Prof. A. Pissart. Département de Géographie Physique et Quaternaire, Université de Liège, Liège, pp. 194-223.

Petit, F., Perpinien, G., Deroanne, C., 2000. Détermination des puissances spécifiques critiques dans des rivières à charge de fond caillouteuse. Revue Géographique de l'Est 40 (1-2), 59-65. 
Piegay, H., Salvador, P.G., Astrade, L., 2000. Réflexions relatives à la variabilité spatiale de la mosaïque fluviale à l'échelle d'un tronçon. Zeitschrift fur Geomorphologie 44 (3), 317-342.

Reid, I., Hassan, M.A., 1992. The influence of microform bed roughness elements on flow and sediment transport in gravel bed rivers: a reply. Earth Surface Processes and Landforms 17, 535-538.

Reille, M., Andrieu, V., Beaulieu, J.L., 1996. Les grands traits de l'histoire de la végétation des montagnes méditerranéennes occidentales. Ecologie 27 (3), 153-169.

Salvador, P.G., 1991. Le thème de la métamorphose fluviale dans les plaines alluviales du Rhône et de l'Isère-Bassin de Malville et Ombilic de Moirans (Isère, France). Thèse de Géographie et Aménagement, Lyon III, 498pp.
Schmitt, L., Maire, G., Humbert, J., 2001. La puissance fluviale: définition, intérêt et limites pour une typologie hydrogéomorphologique des rivières. Zeitschrift fur Geomorphologie 42 (2), 201-224.

Vita-Finzi, C., 1969. The Mediterranean Valleys. Geological Changes in Historical Times. Cambridge University Press, Cambridge, $140 \mathrm{pp}$.

Williams, G.P., 1983. Paleohydrological methods and some example from Swedish fluvial environments: cobble and boulder deposits. Geografiska Annaler 65A, 227-243.

Wolman, M.G., 1954. A method of sampling coarse river-bed material. Transactions of the American Geophysical Union 35 (6), 952-956. 